\title{
HUBUNGAN KERAPATAN MANGROVE DENGAN KELIMPAHAN GASTROPODA DI KAWASAN KONSERVASI MANGROVE DAN BEKANTAN (KKMB) KOTA TARAKAN
}

\section{CORRELATION BETWEEN POPULATIONS WITH GASTROPODA POPULATION IN A CONSERVATION AND MANAGEMENT CONSERVATION (KKMB) COUNTRY CITY}

\author{
Gazali Salim $^{1}$, Dori Rachmawani ${ }^{1}$, Rahmah Agustianisa ${ }^{2}$ \\ ${ }^{1}$ Dosen Program Studi Manajemen Sumberdaya Perairan Fakultas Perikanan dan IImu Kelautan \\ Universitas Borneo Tarakan, Jl. Amal Lama No. 1, Tarakan, North Kalimantan, Indonesia 77115 \\ 2 Mahasiswa Program Studi Manajemen Sumberdaya Perairan Fakultas Perikanan dan IImu Kelautan \\ Universitas Borneo Tarakan \\ corresponding author: nenojali@gmail.com
}

\begin{abstract}
ABSTRAK
Hutan bakau adalah salah satu ekosistem alami yang memberikan kontribusi besar bagi populasi sebagai sumber makanan, salah satunya adalah gastropoda. Tujuan dari penelitian ini adalah untuk menentukan kepadatan bakau, kelimpahan gastropoda dan hubungan antara kepadatan bakau dan kelimpahan gastropoda. Penelitian ini dilakukan pada bulan SeptemberNovember 2018 di area 12 ha KKMB. Metode penelitian yang digunakan adalah metode survei dengan melakukan penelitian langsung pada 12 titik plot dengan ukuran plot $10 \times 10$ meter berada di setiap plot ada 3 sub-plot dibuat 1 x 1 meter dilakukan secara acak dalam plot untuk mengambil sampel gastropoda. Data yang dikumpulkan dikelompokkan berdasarkan variabel tipe, kepadatan mangrove sebagai variabel (X) dan kelimpahan gastropoda sebagai variabel (Y). Hasil penelitian menunjukkan bahwa hasil bakau di daerah yang diperoleh KKMB termasuk dalam kategori sangat baik (baik) dengan nilai 11,700 ind / ha. Kelimpahan gastropoda tertinggi didominasi oleh jenis Cassidula aurisfelis dengan jumlah 79 individu dan kelimpahan terendah dari tipe Littoraria scabra dengan jumlah 14 individu. Tingkat kelimpahan gastropoda yang rendah berkurang karena kepadatan spesies bakau yang rendah dan sumber makanan yang rendah di daerah bakau. Hubungan kepadatan mangrove dengan kelimpahan gastropoda menggunakan analisis regresi linier sederhana diperoleh nilai koefisien determinasi (R2) sebesar 0,227, sedangkan nilai koefisiennya adalah 0,4766 yang artinya berkorelasi positif.
\end{abstract}

Kata kunci: Korelasi, Kepadatan Mangrove, Gastropoda, KKMB

\section{ABSTRCT}

Mangrove forests are one of the natural ecosystems that make a large contribution to the population as a food source, one of which is gastropods. The purpose of this study was to determine the density of mangroves, the abundance of gastropods and the discussion between the density of mangroves and the abundance of gastropods. This research was carried out in September - November 2018 in the area of 12 ha KKMB. The research method used was a survey method by conducting direct research on 12 plot points with a plot size of $10 \times 10$ meters were in each plot there were 3 sub-plots made $1 \times 1$ meter randomly carried out in the plot to take gastropod samples. The collected data are grouped by type variable, mangrove density as a variable $(X)$ and gastropod abundance as a variable $(Y)$. The results showed that the mangrove yields in the area obtained by KKMB belonged to the very solid (good) category with a value of 11.700 ind / ha. The highest gastropod abundance is dominated by 
the type of Cassidula aurisfelis with the number of 79 individuals and the lowest abundance of the type Littoraria scabra with the number of 14 individuals. The low level of gastropod abundance is reduced due to the low density of mangrove species and the low food source in the mangrove area. The relationship of mangrove density with gastropod abundance using simple linear regression analysis obtained the value of determination coefficient (R2) of 0.227, while the coefficient value was 0.4766 which means that it is positively correlated.

Keywords: Correlation, Density Mangrove, Gastropod, KKMB

\section{PENDAHULUAN}

Kota Tarakan merupakan kota yang terletak di Provinsi Kalimantan Utara, Indonesia dan memiliki luas wilayah $250,80 \mathrm{~km}^{2}$. Kota Tarakan atau yang dikenal sebagai Bumi Paguntaka, merupakan pulau kecil yang memiliki semboyan kota "BAIS" (Bersih, Aman, Indah, Sehat, dan Sejahtera). Kota Tarakan memiliki kawasan ekosistem mangrove yang masih tergolong baik dan alami dikarenakan masih minimnya aktivitas masyarakat dan kegiatan lainnya (Badan Pengelolaan Lingkungan Hidup, 2010). Hutan mangrove merupakan suatu komunitas pantai tropis yang di dominasi oleh beberapa spesies pohon yang khas atau semak-semak yang mempunyai kemampuan untuk tumbuh dan berkembang pada daerah pasang surut serta memiliki substrat berlumpur (Bengen, 2002). Hutan mangrove memiliki nilai ekologi paling utama sebagai daerah mencari makan (feeding ground), daerah pemijahan (spawning ground) dan daerah asuhan (nursery ground) bagi ikan, udang, kerang dan gastropoda (Nybakken, 1992). Salah satu hutan mangrove yang terdapat di Kota Tarakan yaitu Kawasan Konservasi Mangrove dan Bekantan (KKMB).

Kawasan Konservasi Mangrove dan Bekantan (KKMB) Kota Tarakan merupakan kawasan ekowisata atau wisata alam yang berada di tengah kota dan memiliki beberapa vegetasi mangrove seperti Avicennia sp., Rhizophora sp.,
Bruguiera sp., Sonneratia alba, dan Nypa fruticans (Taqwa, 2010). Selain vegetasi mangrove salah satu kelompok fauna avertebrata sebagai penghuni ekosistem mangrove yaitu gastropoda.

Gastropoda yang dikenal dengan siput atau keong merupakan kelas yang memiliki anggota terbanyak dalam filum moluska. Gastropoda merupakan salah satu sumber daya hayati yang mempunyai keanekaragaman yang tinggi di ekosistem mangrove dan menempati hutan mangrove sebagai habitat hidupnya (Irawan, 2008).

Hutan mangrove memberikan kontribusi besar terhadap detritus organik sebagai sumber makanan bagi biota yang hidup di perairan sekitarnya. Mikroorganisme seperti bakteri akan mengurai daun-daun yang gugur melalui proses dekomposisi dan hasil dari dekomposisi tersebut dapat dikonsumsi oleh gastropoda dengan menyerap bahan organik yang terkandung didalam substrat (Sirante, 2011).

Penelitian ini bertujuan untuk mengetahui kerapatan mangrove dan kelimpahan gastropoda di daerah perluasan KKMB serta mengetahui korelasi dari kerapatan mangrove dengan kelimpahan gastropoda di daerah perluasan KKMB Kota Tarakan.

\section{METODE PENELITIAN}

Penelitian ini menggunakan metode deskriptif kuantitatif dan survey. Penelitian dilakukan secara langsung di lapangan (insitu) yakni dengan mengamati kerapatan mangrove dan sampel 
gastropoda di daerah perluasan KKMB Kota Tarakan. Penelitian ini dilaksanakan bulan September sampai dengan November 2018. Lokasi pengambilan sampel disajikan pada Gambar 1.

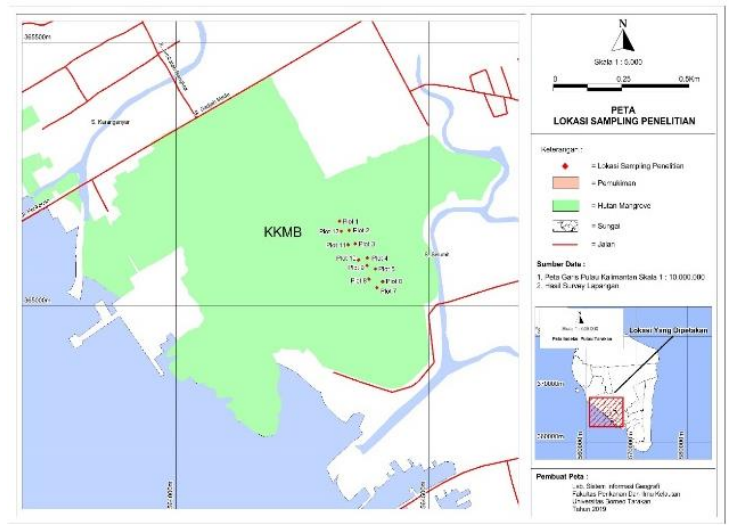

Gambar 1. Peta Lokasi Penelitian

\begin{abstract}
Alat dan Bahan
Alat yang digunakan dalam penelitian meliputi tali rafia, meteran, plastik, kamera, alat tulis, dan GPS (Global Positioning System). Bahan yang digunakan dalam penelitian ini meliputi sampel serasah gastropoda, buku panduan pengenalan mangrove (Noor et al., 2016), dan buku panduan gastropoda (Carpenter dan Niem, 1998).
\end{abstract}

\section{Penentuan Titik Sampling}

Penentuan titik sampling menggunakan metode purposive sampling yang dipastikan terdapat vegetasi mangrove dan gastropoda dengan mendirikan transek/plot sebanyak 12. Penentuan titik sampling juga menggunakan transek yang diletakkan secara acak dan masing-masing transek/plot diletakkan petak contoh berukuran 10x10 $\mathrm{m}^{2}$ dengan jarak antar plot $20 \mathrm{~m}$. Setelah memasang transek/plot maka dilakukan juga pengambilan titik koordinat pada masing-masing plot pengamatan dengan menggunakan Global Positioning System (GPS).

\section{Pengamatan Mangrove}

Pengambilan data mangrove dilakukan dengan menghitung jumlah dan jenis mangrove pada masing-masing petak contoh yang berukuran $(10 \mathrm{x} 10) \mathrm{m}^{2}$. Setiap petak (10x10) $\mathrm{m}^{2}$ terdapat pengukuran untuk vegetasi pohon. Pengambilan data dilakukan seminggu 1 kali dengan mengambil jenis daun, buah, dan akar mangrove untuk setiap jenis mangrove untuk keperluan mendapatkan komposisi jenis mangrove yang di identifikasi berdasarkan buku Pengenalan Mangrove Indonesia karangan Noor et al., 2006.

\section{Pengamatan Gastropoda}

Sampel gastropoda diambil di dalam transek/plot pengamatan berukuran (10x10) $\mathrm{m}^{2}$. Dalam setiap transek/plot ukuran contoh tersebut dibuat sub plot dengan tiga titik, dimana masing-masing titik tersebut menggunakan transek (1x1) $\mathrm{m}^{2}$. Pengambilan sampel dilakukan pada saat air surut sehingga mempermudah dalam menghitung dan mengidentifikasi jenis-jenis gastropoda. Gastropoda yang diambil berada di permukaan substrat (epifauna) dan yang menempel pada akar, batang dan daun mangrove (treefauna). Selanjutnya sampel dimasukkan ke dalam plastik dan diberi label untuk keperluan identifikasi berdasarkan buku Panduan Gastropoda karangan Carpenter dan Niem, 1998.

\section{Analisis Data}

Data-data yang diperoleh dari hasil pengamatan dianalisa dan disajikan dalam grafik dan tabel. Analisis yang digunakan dalam mengolah data tersebut yaitu :

\section{1) Kerapatan Mangrove}

Kerapatan jenis (Ki) adalah jumlah tegakan jenis $I$ dalam suatu unit area. Untuk mengetahui kerapatan jenis mangrove dengan menggunakan rumus (English et al., 1994 dalam Parmadi, 2016):

$$
\mathrm{Ki}=\frac{\text { ni }}{\mathrm{A}}
$$

Dimana :

$\mathrm{K}_{\mathrm{i}} \quad$ : Kerapatan jenis ke- $i$ (ind/ha)

ni : Jumlah total tegakan ke- $i$

A : Luas area total pengambilan sampel $\left(100 \mathrm{~m}^{2}\right)$ 


\section{2) Komposisi Jenis Mangrove}

Komposisi merupakan persentase jumlah individu suatu jenis mangrove di semua lokasi pengamatan berdasarkan total seluruh individu. Komposisi tumbuhan dapat diartikan sebagai variasi jenis flora yang menyusun suatu komunitas (Dachlan, 2013). Perhitungan nilai komposisi ini berdasarkan rumus :

$$
\begin{gathered}
\text { Komposisi }=\text { ind. suatu jenis } \\
\text { Total ind. seluruh jenis }
\end{gathered}
$$

\section{3) Kelimpahan Gastropoda}

Analisis kelimpahan (ind $/ \mathrm{m}^{2}$ ) gastropoda di KKMB berdasarkan jumlah individu persatuan luas dihitung dengan menggunakan rumus (Bakus, 1990 dalam Haryoardyantoro et al., 2013).

$$
\mathrm{A}=\frac{\mathrm{Xi}}{\mathrm{Ni}}
$$

Dimana :

$\mathrm{A}=$ Kelimpahan individu (ind $/ \mathrm{m}^{2}$ )

$\mathrm{Xi}=$ Jumlah individu

$\mathrm{Ni}=$ Luas plot pengamatan $\left(100 \mathrm{~m}^{2}\right)$

\section{4) Koefesien Regresi}

Koefesien korelasi adalah pengukuran statistik kovarian atau asosiasi antara 2 variabel. Besarnya koefesies korelasi berkisar antara +1 s/d -1 . Koefesien korelasi menunjukkan kekuatan (streght) hubungan linear dan arah hubungan dua variabel acak. Jika koefesien korelasi positif, maka kedua variabel mempunyai hubungan searah, artinya jika nilai variabel $\mathrm{X}$ tinggi, maka nilai variabel $\mathrm{Y}$ akan tinggi pula. Sebaliknya, jika koefesin korelasi negatif, maka kedua variabel mempunyai hubungan terbalik, artinya jika nilai $\mathrm{X}$ tingi, maka nilai variabel $Y$ akan menjadi rendah dan berlaku sebaliknya. Untuk memudahkan melakukan interpretasi mengenai kekuatan hubungan antara dua variabel penulis memberikan kriteria sebagai berikut (Sarwono, 2006).

Tabel 1. Nilai Kriteria Hubungan Korelasi

\begin{tabular}{ccc}
\hline No & Interval Nilai & Kekuatan Hubungan \\
\hline 1 & 0 & Tidak ada korelasi \\
2 & $>0-0,25$ & Korelasi sangat lemah \\
3 & $>0,25-0,5$ & Korelasi cukup \\
4 & $>0,5-0,75$ & Korelasi kuat \\
5 & $>0,75-0,99$ & Korelasi sangat kuat \\
6 & 1 & Korelasi sempurna \\
\hline
\end{tabular}

\section{HASIL DAN PEMBAHASAN}

\section{Gambaran Umum Lokasi Penelitian}

Kawasan Konservasi Mangrove dan Bekantan (KKMB) terletak pada koordinat $3^{\circ} 18^{\prime} 10^{\prime \prime}-3^{\circ} 18^{\prime} 22^{\prime \prime}$ LU dan 117 $34^{\prime} 30^{\prime \prime}$ $117^{\circ} 34^{\prime} 43^{\prime \prime}$ BT. Kawasan seluas \pm 9 ha (panjang $\pm 406 \mathrm{~m}$ dan lebar $\pm 220 \mathrm{~m}$ ) ini merupakan tempat ekowisata yang berada di tengah Kota Tarakan. Pada tahun 2006 KKMB diperluas menjadi 22 ha atas kesepakatan dan dukungan pemerintah Kota Tarakan dan DPRD Kota Tarakan (Badan Pengelola Lingkungan Hidup, 2010). Kawasan ini berdampingan dengan pemukiman padat penduduk, termasuk didalamnya pasar tradisional, cold storage dan pelabuhan perikanan. KKMB mendapat masukan air tawar dari kawasan pemukiman padat di sekitar area mangrove. Aliran air tawar yang membawa air limbah domestik dari kawasan pemukiman masuk ke dalam kawasan melalui selokan yang berda di sudut utara hutan mangrove. Pada saat pasang air laut masuk kedalam kawasan dari perairan Selat Tarakan melalui sungai pasang surut yang terdapat di KKMB (Taqwa, 2010). 


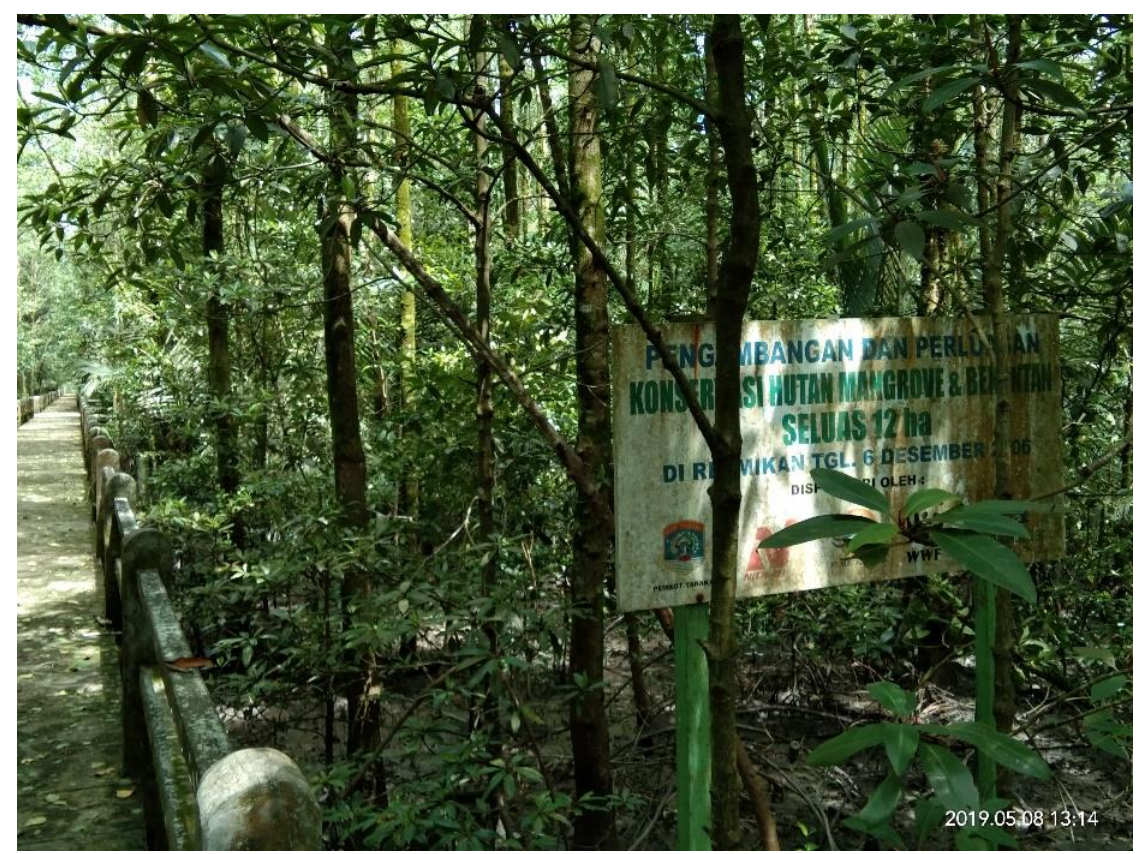

Gambar 2. Daerah perluasan 12 ha KKMB

Berdasarkan pengelolaannya dibagi menjadi kawasan hutan alam seluas 9 hektar dengan jenis mangrove asli dan kawasan perluasan seluas 12 ha dengan 8 jenis mangrove yang ditanam. Jenis mangrove yang ditemukan pada daerah perluasan 12 ha yaitu jenis Rhizophora sp, Avicennia sp, Sonneratia alba dan Nypa Fruticans. Menurut Kasriadi (2019) bahwa di daerah perluasan 12 ha terdapat 5 jenis mangrove yaitu Rhizophora sp, Sonneratia $\mathrm{sp}$, Avicennia sp, Bruguiera sp dan Nypa fruticans. Menurut Septiani (2015), bahwa terdapat beberapa gastropoda di KKMB yaitu Telescopium telescopium, Littoraria scabra, Chicoreus capucinus, Cerithidea sp., dan Cerithidea quadrata.

\section{Kerapatan Jenis Mangrove}

Hasil Penelitian ini menyatakan bahwa di ekosistem hutan mangrove KKMB Kota Tarakan khususnya perluasan 12 ha terdiri dari 4 spesies yaitu Rhizopora apiculata, Rhizophora mucronata, Sonneratia alba dan Nypa fruticans. Jenis mangrove yang mendominasi di daerah perluasan KKMB yaitu dari jenis Sonneratia alba. Kerapatan Mangrove di perluasan KKMB dapat dilihat pada tabel 2 .

Tabel 2. Kerapatan Jenis Mangrove

\begin{tabular}{|c|c|c|c|c|c|}
\hline \multirow[b]{2}{*}{ Plot } & \multicolumn{4}{|c|}{ Jenis Mangrove (Ind/100 $\mathrm{m}^{2}$ ) } & \multirow[b]{2}{*}{ Jumlah } \\
\hline & $\begin{array}{c}\text { Rhizophora } \\
\text { apiculata }\end{array}$ & $\begin{array}{c}\text { Rhizophora } \\
\text { mucronata }\end{array}$ & $\begin{array}{c}\text { Sonneratia } \\
\text { alba }\end{array}$ & $\begin{array}{c}\text { Nypa } \\
\text { fruticants }\end{array}$ & \\
\hline 1 & 1 & 1 & 12 & 3 & 17 \\
\hline 2 & 1 & 2 & 2 & 2 & 7 \\
\hline 3 & 0 & 5 & 0 & 3 & 8 \\
\hline 4 & 3 & 3 & 0 & 0 & 6 \\
\hline 5 & 4 & 0 & 1 & 2 & 7 \\
\hline 6 & 0 & 2 & 12 & 0 & 14 \\
\hline 7 & 2 & 0 & 7 & 0 & 09 \\
\hline 8 & 0 & 0 & 9 & 2 & 11 \\
\hline
\end{tabular}




\begin{tabular}{cccccc}
\hline 9 & 3 & 1 & 5 & 0 & 9 \\
10 & 5 & 3 & 2 & 0 & 10 \\
11 & 1 & 2 & 3 & 2 & 8 \\
12 & 4 & 1 & 6 & 0 & 11 \\
\hline Total & 24 & 20 & 59 & 14 & 117 \\
\hline
\end{tabular}

Dari hasil penelitian kerapatan jenis tertinggi terdapat pada plot 1 sebesar 17 ind $/ 100 \mathrm{~m}^{2}$. Tingginya kerapatan jenis di lokasi ini karena kondisi lingkungan seperti substrat berlumpur cocok dengan jenis mangrove yang ada, kurangnya sampah plastik disekitar plot sehingga tidak menghambat pertumbuhan mangrove serta jarak antar pohon yang satu dengan yang lain tidak terlalu jauh. Hal ini sesuai dengan pendapat Susanti dalam Firdaus (2013) bahwa kehadiran suatu jenis dalam suatu vegetasi merupakan petunjuk bahwa secara alami jenis itu di anggap cocok dengan lingkungan vegetasi daerah tersebut.

Kerapatan mangrove terendah terdapat pada plot 4 sebesar 6 ind/100 $\mathrm{m}^{2}$. Rendahnya kerapatan jenis di plot ini diduga karena kurangnya jumlah pohon dan jarak antara pohon yang satu dengan lain relatif renggang, kurang cocoknya jenis substrat dengan jenis mangrove, tingkat salinitas air, pasokan air tawar yang kurang dan tertutupnya mangrove oleh sampah plastik yang terbawa oleh aliran pasang surut sehingga pertumbuhan mangrove kurang baik. Hal ini sesuai dengan pendapat Petra et al. (2012) yang menyatakan bahwa rendahnya kemampuan regenerasi untuk tingkat pohon disebabkan oleh berbagai hal seperti individu yang tertutup oleh sampah plastik dan mangrove yang mati sehingga mengurangi jumlah tegakan untuk tingkat pohon. Pasokan air tawar dan salinitas air merupakan faktor yang paling berpengaruh terhadap pertumbuhan magrove, bila mangrove tidak mampu beradaptasi dengan kondisi lingkungan yang ada dapat mengakibatkan kemampuan tumbuhnya akan sedikit terhambat.

\section{Kerapatan Populasi Mangrove}

Kerapatan populasi mangrove yang terdapat di daerah perluasan KKMB dapat dilihat pada Tabel 3 berikut :

Tabel 3. Kerapatan Populasi Mangrove

\begin{tabular}{|c|c|c|c|c|}
\hline \multicolumn{2}{|c|}{ Jumlah Individu } & & \multirow[b]{2}{*}{ Kategori } & \multirow{3}{*}{$\begin{array}{l}\text { KepMen } \\
\text { LH No.201 } \\
\text { Tahun } \\
2004\end{array}$} \\
\hline $\begin{array}{c}\text { KKMB (Perluasan } \\
12 \text { ha) }\end{array}$ & Baku Mutu (Ind/ha) & & & \\
\hline $11.700 \mathrm{Ind} / \mathrm{ha}$ & $\begin{array}{c}\geq 1500 \\
\geq 1000-<1500 \\
<1000\end{array}$ & $\begin{array}{l}\text { Baik } \\
\text { Rusak }\end{array}$ & $\begin{array}{l}\text { Sangat Padat } \\
\text { Sedang } \\
\text { Jarang }\end{array}$ & \\
\hline
\end{tabular}

Berdasarkan tabel 6 diketahui bahwa kerapatan populasi mangrove di perluasan 12 ha KKMB sebesar 11.700 ind/ha, menurut baku mutu kerusakan hutan mangrove KepMen LH No.201 Tahun 2004 daerah perluasan 12 ha memiliki nilai $\geq$ $1500 \mathrm{ind} / \mathrm{ha}$ artinya masuk kedalam kategori kerapatan mangrove sangat padat (baik). Lokasi perluasan 12 ha ini memiliki kerapatan sangat padat karena daerah tersebut tidak tersentuh pembangunan untuk pemukiman, tambak serta menjadi daerah konservasi dan banyak mendapatkan pasokan air tawar. Akbar et al (2016) menjelaskan bahwa tingginya nilai kerapatan mengindikasi tingkat regenerasi jenis mangrove tergolong baik dan dapat bertahan pada kondisi lingkungan yang ada. 


\section{Komposisi Jenis Mangrove}

Komposisi merupakan persentase jumlah individu suatu jenis mangrove disemua lokasi pengamatan berdasarkan total seluruh individu. Komposisi tumbuhan dapat diartikan sebagai variasi jenis flora yang menyusun suatu komunitas. Komposisi jenis mangrove pada daerah perluasan 12 ha dapat dilihat pada Gambar 3.

\section{Komposisi Hasil Penelitian Jenis Mangrove}

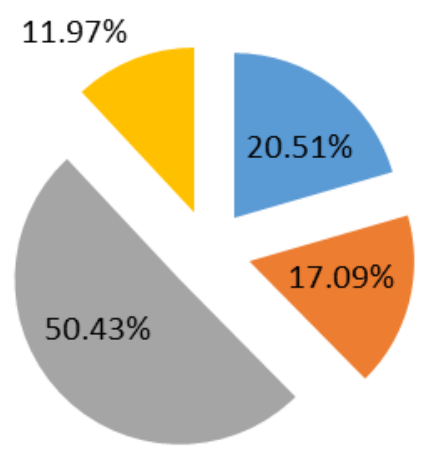

- Rhizopora apiculata

Rhizopora mucronata

Sonneratia alba

Nypa fruticans

Gambar 3. Jumlah Komposisi Jenis Mangrove di Perluasan 12 ha

Berdasarkan gambar 3, setiap jenis mangrove memiliki persentase jenis yang berbeda-beda seperti jenis Rhizophora apiculata (24 individu) 20,51\%, Rhizophora mucronata (20 individu) 17,09 $\%$, Sonneratia alba (59 individu) 50,43\%, dan Nypa fruticans (14 individu) 11,97\%. Perbedaan komposisi jenis mangrove diduga karena zonasi yang berbeda dan jenis substrat dari masing-masing mangrove tersebut berbeda. Menurut Taqwa (2010) perbedaan komposisi jenis mangrove disetiap kerapatan disebabkan oleh karakteristik dari masing-masing jenis terhadap habitatnya. Jarak setiap kerapatan dari garis pantai berbeda, sehingga dapat mengakibatkan perbedaan salinitas substrat, frekuensi penggenangan oleh air pasang dan komposisi substrat.

\section{Kelimpahan Gastropoda}

Kelimpahan gastropoda di KKMB khususnya daerah perluasan 12 ha di duga berlimpah. Gastropoda dilokasi ini memiliki kelimpahan yang berbeda-beda dari setiap plot pengamatannya. Hasil penelitian kelimpahan gastropoda di daerah perluasan KKMB dapat dilihat pada Tabel 4.

Tabel 4. Spesies Gastropoda yang didapatkan pada lokasi penelitian

\begin{tabular}{llllllllllllllll}
\hline \multirow{2}{*}{ No } & \multicolumn{1}{c}{ Spesies } & \multicolumn{11}{c}{ Plot Pengamatan $\left(\mathrm{Ind} / \mathrm{m}^{2}\right)$} & \multicolumn{1}{c}{ Jumlah } \\
\cline { 2 - 12 } & 1 & 2 & 3 & 4 & 5 & 6 & 7 & 8 & 9 & 10 & 11 & 12 & \\
\hline \multirow{2}{*}{1} & Telescopium & 5 & 2 & 3 & 1 & 4 & 3 & 1 & 0 & 4 & 2 & 2 & 4 & 31 \\
& telescopium & Cassidula aurisfelis & 9 & 5 & 2 & 5 & 7 & 6 & 5 & 11 & 8 & 12 & 5 & 4 & 79 \\
3 & Littoraria scabra & 2 & 2 & 0 & 1 & 2 & 0 & 1 & 2 & 0 & 1 & 0 & 3 & 14 \\
4 & Nerita articulata & 2 & 3 & 1 & 2 & 0 & 0 & 2 & 5 & 0 & 0 & 2 & 0 & 17 \\
\hline
\end{tabular}




\begin{tabular}{ccccccccccccccc}
\hline 5 & Cerithidea obtusa & 3 & 4 & 1 & 4 & 4 & 5 & 0 & 3 & 4 & 1 & 2 & 3 & 34 \\
6 & Cerithidea cingulata & 2 & 0 & 0 & 0 & 0 & 0 & 0 & 4 & 5 & 6 & 3 & 2 & 22 \\
7 & Chicoreus capucinus & 4 & 5 & 4 & 2 & 5 & 4 & 4 & 0 & 0 & 2 & 0 & 0 & 30 \\
\hline & Jumlah & 27 & 21 & 11 & 15 & 22 & 18 & 13 & 25 & 21 & 24 & 14 & 16 & 227 \\
\hline
\end{tabular}

Jenis yang paling banyak ditemukan yaitu Cassidula aurisfelis sebanyak 79 individu. Hal ini dikarenakan banyak di temukan pada substrat berlumpur dan sumber makanan yang ada pada substrat mendukung bagi kehidupan gastropoda jenis ini. Cassidula aurisfelis biasa memakan bahan organik serasah dan alga. Serupa dengan penelitian Haryoardyantoro et al., (2013) bahwa sebagian besar gastropoda memiliki pola penyebaran mengelompok diduga karena daerah hutan mangrove tersebut memiliki kondisi lingkungan yang optimum bagi kelangsungan hidup gastropoda.

Jenis gastropoda yang paling sedikit ditemukan pada daerah perluasan yaitu jenis jenis Littoraria scabra sebanyak 14 individu. Hal ini dikerenakan jenis tersebut memiliki habitat yang hidup di daerah rawa-rawa dan ditepi arah laut dari kawasan mangrove serta biasa menempel di daun nipah sehingga jenis tersebut tidak banyak mendapatkan sumber makanan. Menurut Alfaro (2008) L. scabra adalah hewan herbivora yang sebagian besar makanannya diperoleh selama periode surut pada bagian bawah pohon mangrove (akar dan batang), sedangkan pada bagian atas pohon mangrove (ranting dan daun) tersedia dalam jumlah terbatas selama periode pasang.

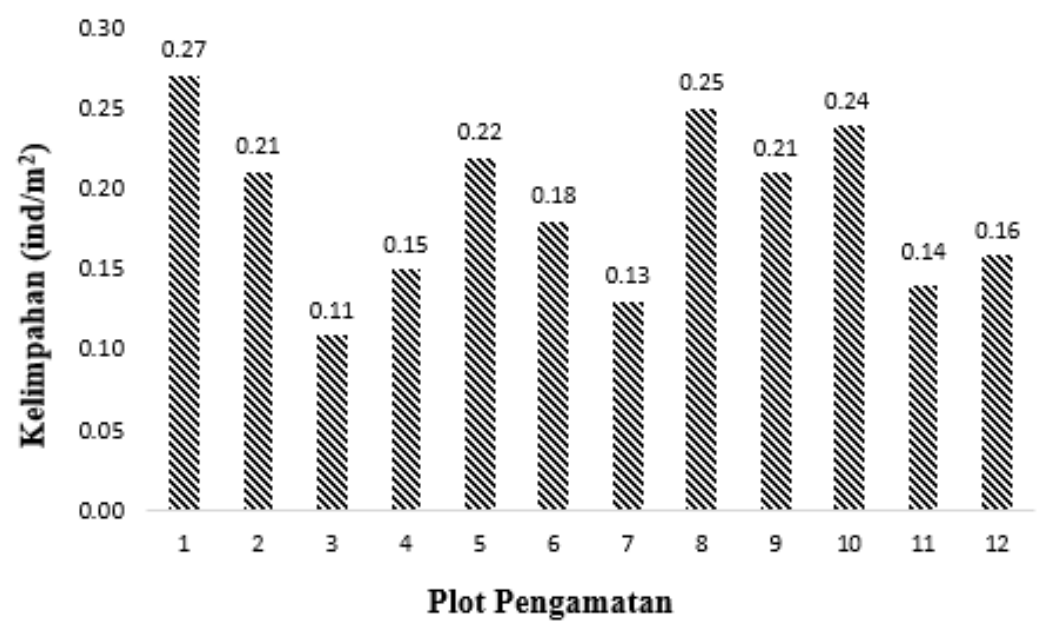

Gambar 4. Grafik kelimpahan Gastropoda

Berdasarkan Gambar 4, kelimpahan tertinggi terdapat pada plot 1 yaitu sebesar berada pada ekosistem mangrove dengan kondisi yang cukup bagus serta tingginya kandungan bahan organik sedimen dan tipe substrat yang mendukung untuk pertumbuhan gastropoda. Wijayanti (2007) menjelaskan bahwa substrat di dasar perairan akan menentukan kelimpahan dan komposisi jenis dari hewan benthos. Kandungan bahan organik dalam substrat
0,27 individu $/ \mathrm{m}^{2}$. Tingginya kelimpahan tersebut di duga karena daerah tersebut akan mempengaruhi persebaran dan jumlah kelimpahan makrobenthos di dalamnya.

Kelimpahan terendah terdapat pada plot 3 . Rendahnya kelimpahan gastropoda disebabkan oleh rendahnya bahan organik di area plot tersebut, serta kerapatan mangrove yang rendah. Rendahnya bahan organik menyebabkan menurunnya ketersediaan bahan makanan sehingga tidak 
banyak gastropoda yang menghuni di area tersebut. Hal ini sesuai dengan pendapat Silaen et al., (2013) kelimpahan dan distribusi gastropoda dipengaruhi oleh lingkungan habitat spesies tersebut, ketersediaan makanan, pemangsaan dan kompetesi antar spesies. Tekanan ekologis dan perubahan lingkuhan seperti vegetasi dapat mempengaruhi kelimpahan organisme yang hidup didalamnya.

\section{Korelasi Kerapatan Mangrove Dengan Kelimpahan Gastropoda}

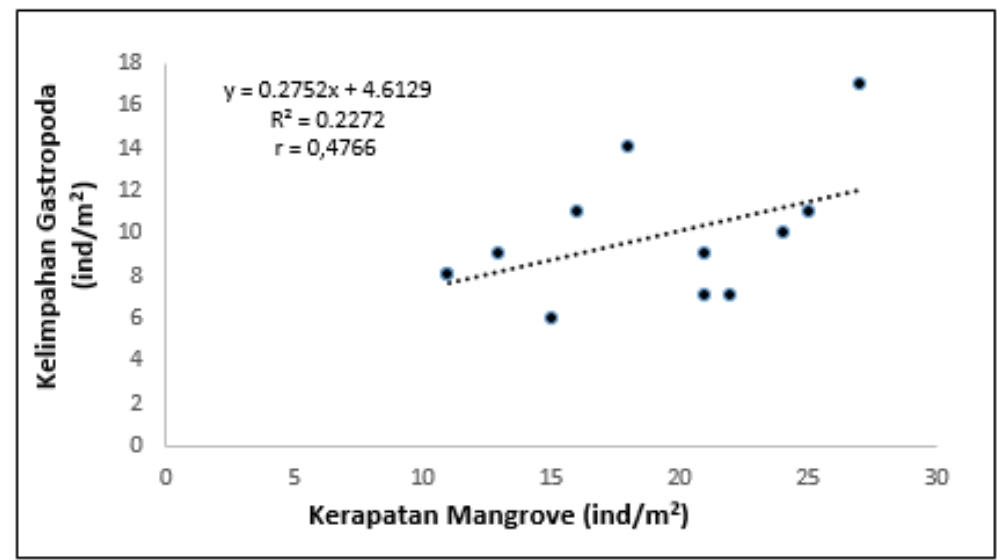

Gambar 5. Grafik Korelasi Kerapatan Mangrove dengan Kelimpahan Gastropoda

Hasil perhitungan dengan analisis regresi linier sederhana untuk mengetahui besarnya hubungan antar variabel $\mathrm{X}$ (kerapatan mangrove) dan variabel $\mathrm{Y}$ (kelimpahan gastropoda) di daerah perluasan KKMB dapat ditunjukkan denga persamaan $\mathrm{y}=$ $0,2752 \mathrm{x}+4,6129$ memiliki hubungan positif artinya setiap kenaikan terhadap variabel $\mathrm{X}$ akan mengakibatkan kenaikan terhadap variabel, dengan asumsi faktor lain tetap dan tidak berubah. Koefesien determinasi (R2) yang diperoleh adalah 0,2272. Nilai korelasi (r) yang diperoleh adalah 0,4766 artinya pengaruh kerapatan mangrove dengan kelimopahan gastropoda sebesar $48 \%$ dan $52 \%$ dipengaruhi oleh variabel lain seperti sedimen, bahan organik dan ketersediaan cahaya matahari. Berdasarkan nilai kriteria hubungan korelasi, nilai r 0,4766 termasuk korelasi cukup. Hal ini didukung oleh penelitian Talib (2008), bahwa tidak semua makrozoobentos (gastropoda) memiliki hubungan erat dengan vegetasi mangrove.

\section{KESIMPULAN}

Hasil penelitian dapat disimpulkan bahwa berdasarkan perhitungan dengan analisis regresi linier sederhana kerapatan mangrove dengan kelimpahan gastropoda terdapat hubungan positif antar keduanya dengan nilai korelasi sebesar 0,4766 yang berarti berkorelasi cukup.

\section{UCAPAN TERIMAKASIH}

Ucapan Terimakasih diberikan kepada Rahmah Agustianisa yang telah mendedikasikan hasil penelitian skripsi untuk dapat di publikasikan dalam Jurnal Harpodon Borneo Tahun 2019 dengan Judul Skripsi Hubungan Kerapatan Mangrove Dengan Kelimpahan Gastropoda Di Kawasan Konservasi Mangrove dan Bekantan (KKMB) Kota Tarakan

\section{DAFTAR PUSTAKA}

Akbar N, Baksir A, Tahir I, Arafat D. (2016). Struktur Komunitas Mangrove di Pulau Mare, Kota 
Tidore Kepulauan, Maluku Utara, Indonesia. Depik, 5(3): 133-142.

Alfaro, A. C. (2008). Diet of Littorina scabra, while Vertically Migrating on Mangrove Trees: Gut Content, Fatty Acid and Stable Isotope Analyses. Estuarine, Coastal and Shelf Science Journal. 79 (4): 718726.

Badan Pengelolaan Lingkungan Hidup. (2010). Laporan penelitian KKMB Kota Tarakan. Tarakan: Badan Pengelolaan Lingkungan Hidup.

Bengen, D. G. (2002). Pedoman Teknis Pengenalan dan Pengelolaan Ekosistem Mangrove. Pusat Kajian Sumberdaya Pesisir dan Lautan. IPB. Bogor.

Carpenter, K.E. dan Niem, V.H (eds). (1988). The Living Marine Resources Of The Western Central Fasifik. Introduction, Gastropoda, Bivalvia, Coral and Seagrass. FAO Spesies Identification Guide For Fishery Purpose and American Scienty Of Ichthyol Rome, FAO. Vol 2. PP. 1600.

Dachlan, R. (2013). Struktur Vegetasi Mangrove di Kampung Iseren Pulau Rumberpon Pada Kawasan Taman Nasional Teluk Cendrawasih. Universitas Negeri Papua. Papua.

English. (1994). Survey Manual for Tropical Marine Resources. Australian Institute.

Firdaus, M. (2013). Struktur Komunitas Vegetasi Mangrove di Pantai Desa Jangkang Kabupaten Bengkalis Provinsi Riau. Skripsi Sarjana, Fakultas Perikanan dan Ilmu
Kelautan Universitas Riau. 53 hal (tidak diterbitkan).

Haryoardyantoro S, Hartati R, Widianingsih. (2013). Komposisi dan Kelimpahan Gastropoda di Vegetasi Mangrove Kelurahan Tugurejo, Kecamatan Tugu, Kota Semarang. Journal of Marine Research. 2(2):85-93.

Irawan, I. (2008). Struktur Komunitas Moluska (Gastropoda dan Bivalvia) serta Distribusinya di Pulau Burung dan Pulau Tikus Gugus Pulau Pari Kepulauan Seribu. Departemen Biologi Fakultas Matematika dan Ilmu Pengetahuan Alam Institut Pertanian Bogor, Bogor.

Kasriadi. (2019). Korelasi Antara Kerapatan Mangrove dan Kepadatan Kerang Kapah di Daerah Perluasan 12 Hektar KKMB Kota Tarakan. Skripsi Sarjana, Manajemen Sumberdaya Perairan, Fakultas Perikanan dan Ilmu Kelautan Universitas Borneo Tarakan, Tarakan.

Noor, Y. R. Khazali, M. Suryadiputra, I. N. N. (2006). Panduan Pengenalan Mangrove di Indonesia. Wetlands International-Indonesia Programme. Bogor.

Nybakken, J. W. (1992). Biologi Laut: Suatu Pendekatan Ekologis. PT. Gramedia.Jakarta.

Petra, J.L., S. Sastrawibawa dan I. Riyantini. 2012. Pengaruh Kerapatan Mangrove Terhadap Laju Sedimen Transpor di Pantai Karangsong Kabupaten Indramayu. Jurnal Perikanan dan Kelautan. 3 (3): 329-337. 
Sarwono, J. (2006). Metode Penelitian Kuantitatif dan Kualitatif. Yogyakarta: Graha Ilmu

Septiani, F. (2015). Struktur Komunitas Gastropoda di Kawasan Konservasi Mangrove dan Bekantan (KKMB) Kota Tarakan. Skripsi. Jurusan Manajemen Sumberdaya Perairan, Fakultas Perikanan Universitas Borneo Tarakan, Tarakan.

Silaen I. F., Hendrarto B dan Supardjo M. N. (2013). Distribusi dan Kelimpahan Gastropoda pada Hutan Mangrove Teluk Awur Jepara. Journal Of Management Of Aquatic Resources. 2(3): 93103.

Sirante, R. (2011). Studi Struktur Komunitas Gastropoda di Lingkungan Perairan Mangrove Kelurahan Lappa dan Desa Tongka-Tongke Kabupaten Sinjai. Skripsi Sarjana, Institut Pertanian Bogor, Bogor.
Talib, M.F. (2008) Struktur dan Pola Zonasi (Sebaran) Mangrove Serta Makrozoobentos yang Berkeksistensi di Desa Tanah Merah dan Oebolo Kecil Kabupaten Kupang. Skripsi. IPB. Bogor.

Taqwa, A. (2010). Analisis Produktifitas Primer Fitoplankton dan Struktur Komunitas Fauna Makrobenthos Berdasarkan Kerapatan Mangrove di Kawasan Konservasi Mangrove dan Bekantan Kota Tarakan, Kalimantan Timur. Tesis Magister, Manajemen Sumberdaya Pantai, UNDIP, Semarang.

Wijayanti, H. (2007). Kualitas Perairan di Pantai Kota Bandar Lampung Berdasarkan Komunitas Hewan Makrobenthos. Tesis Magister Sains, Program Pascasarjana, Universitas Diponegoro. Semarang. 